\title{
Action Research: CPA Math Word Wall Group Competition to Improve Conceptual Understanding in Algebra Problem Solving Activities
}

\author{
Heru Kurniawan ${ }^{1, *}$ Supriyono Supriyono ${ }^{1}$, Tursilowati Tursilowati ${ }^{2}$, \\ Iswati Jeni Kustiningsih ${ }^{3}$ \\ ${ }^{1}$ Mathematrics Education, Muhammadiyah University of Purworejo, Purworejo, Indonesia
${ }^{2}$ Mathematics Teacher in SMP N 12 Purworejo, Purworejo, Indonesia
${ }^{3}$ Mathematics Teacher in SMP N 4 Purworejo, Purworejo, Indonesia
${ }^{*}$ Corresponding author. Email: herukurniawan@ umpwr.ac.id
}

ABSTRACT

This Classroom Action Research (CAR) aims to overcome the low understanding of algebraic concepts and anxiety by applying the CPA math word wall group competition. CAR is carried out in 3 cycles. CAR is imposed on 327 th grade students of SMP N 12 Purworejo. The research instrument used observation sheets and essay tests. The data analysis technique used a paired sample T-test to see an increase in concept understanding. The results of the study indicate that the application of CPA math word wall group competition can improve students' conceptual understanding.

Keywords: CPA Approach, Math Word Wall, Conceptual Understanding, Algebra.

\section{INTRODUCTION}

Algebra is an abstract mathematical concept. To learn something abstractly, students need to have abstract thinking [1]. Success in learning algebra depends on the ability to think in several appropriate ways to display productive algebraic performance [2]. Initially, algebra was mostly more rhetorical which involved the use of words and sentences, but nowadays, algebra has developed into a form of syncopation where words and actions are expressed in the form of abbreviations (variables) that represent words and sentences used previously [3]. Therefore, many students think that algebra is just playing with the $\mathrm{x}$ or $\mathrm{y}$ symbol, even though it is not the case. This assumption becomes the door for misconceptions and difficulties in learning algebra properly. Therefore, algebra must be considered as a complex system used in problem-solving activities. When people think algebraically to solve problems, various thinking habits will be involved, such as making mathematical model equation rules and doing computations [1].

One of the significant problems experienced by many students in learning algebra is an understanding of variables [4]. Variable is an important concept that gives color to the mathematics curriculum. Understanding of variables is always associated with the concept of algebra. In general, there are various forms of representation of variables which are usually denoted by letter symbols. The letter symbols that represent these variables are the cause of difficulties and misconceptions in learning algebra, this is because students are confused about understanding symbolic representations as a substitute for something [5] . In addition to difficulties in understanding variables, students also have difficulty understanding the meaning of the equal sign (=) which is commonly used in algebraic operations. Students 'understanding of the equal sign (=) affects algebraic learning [6], this will affect students' interpretation of whether " $=$ " means that both sides of the equation are the same and can be exchanged.

In the case of Indonesia, the teachers stated that students often made mistakes in algebraic concepts, including $\mathrm{x}+\mathrm{x}=\mathrm{x}^{2}$, or $\mathrm{x} . \mathrm{x}=2 \mathrm{x}$. Although the error may seem far-fetched, in many classes it was real. In some cases, students find it easy to solve problems that only involve mechanistic abilities and perform simple operations. However, when faced with story questions, 
students began to worry and often experienced difficulties. Types of story problems that often cause problems include questions that involve several concepts at once, questions that involve relationships (less than, more than, multiples, etc.), and complex story problems. Students' difficulties are thought to be the result of a lack of understanding of concepts The main concern in the school mathematics curriculum is students' understanding of the correct mathematical concepts [7]. One of the main keys in learning school mathematics is mastery of concepts [8]. A good understanding of a previous concept plays an important role in understanding new concepts [9].

Teaching how to solve algebraic equations is important for improving mathematical literacy, both for developing students, but also for students with intellectual disabilities [10]. Teachers need to develop insights into students 'thinking to identify students' difficulties and mistakes in understanding algebra [11]. One of the learning approaches that can be used to reduce the difficulty of learning algebra is the ConcretePictorial-Abstract (CPA) approach. The CPA approach is suitable for students at the elementary level, junior high school students, to higher levels [12].

Learning with the CPA approach was carried out in three stages. First, implemented concretely or using manipulative materials and models. Second, through the use of images, tables, or two-dimensional objects that represent previous concrete objects. Third, through the use of mathematical symbols such as letters and numbers [13]. The use of concrete objects includes manipulative objects such as cakes, cars, fruit, containers, or other objects that can be used for learning. Representation is a form of representative image of previous concrete objects. Symbolic representations are abstract forms such as numbers or letters that are interpreted when solving problems [14]. In this study, the concrete forms were presented in the form of pieces of the image as a wake of the real concrete form. Representatives can be presented in the form of boxes or other images that were interpreted as concrete objects. Abstracts were presented in the form of mathematical symbols, in algebra abstract forms are defined as variables. In this study, the CPA approach will be applied to problem-solving activities. This aims to create meaningful learning. The best way to engage students in algebraic thinking is to give them meaningful problems worth thinking about, such as current events in politics, sports, science, or entertainment [15].

Wahlstrom states that elementary school teachers are excited and interested in learning more about word walls, particularly about how to use them in mathematics (readingrockets.org). Although initially the word wall is widely used to learn vocabulary and language, it can also be developed for the benefit of learning mathematics, then this is called a math word wall. The purpose of the Mathematics Word Wall is to identify words and phrases (mathematical language) that students need to understand and use to make good progress in mathematics. Mathematical language is very important for the development of children's thinking. If students do not have the vocabulary to convey ideas about math concepts and skills, they cannot make progress in understanding mathematics itself. Students should familiarize themselves with using math vocabulary and mathematical terms to understand written and spoken instructions (readingrockets.org).

Math Word Wall can serve as an extension of mathematics teaching. When students experience deadlock, they can quickly connect to the visualization of the Math Word Wall [16]. Math word wall can be used to improve students' mathematical understanding for the following reasons: greater student independence, keeping the class on track and inviting classroom, connection to previous topics, and low floor and high ceiling [17]. This study will take advantage of the math word wall to display the results of discussions and student work with the aim that students can at any time review the concepts that he and other friends have thought of. Thus, understanding the concept will be maintained for a long time.

Referring to the problems presented earlier, it was very important to study more deeply how the presentation of learning can strengthen conceptual understanding. Several previous studies related to algebra that these studies mainly focus on the transition process from arithmetic to algebra, student misconceptions regarding algebra, sources of errors, and the challenges they face in algebra [1]. In their research, conducted a study to evaluate the performance of grade 6 students related to algebraic problems prepared at the level of declarative, procedural, and conditional knowledge, and to investigate achievement levels based on gender variables [1]. The research findings concluded that through the CPA approach, students in grades six and seven who experience learning difficulties obtain high test results on algebraic transformations [18]. Other research also concluded that the CPA approach can improve students' mathematical, spatial, and independent representation [19]. In contrast to previous studies, this study will examine in depth how the application of the CPA approach to increasing understanding of algebraic concepts and decreasing student anxiety. Understanding the concepts of algebra will be used for mathematical problem-solving activities (questions that are challenging and require non-standard solving procedures).

To answer this, this study modifies the application of the CPA approach in the form of group discussions in which the results of the discussion will be assessed and posted on the math word wall. Assessment of the results 
of student discussions will be displayed in table standings to see the winners at the end of the meeting to create competition between groups. It is felt that not many have done this approach modification, so researchers are very interested in applying it and examining the extent to which it affects concept understanding.

Based on the study of the problems above, the questions posed in this study are: can students' understanding of concepts be improved through the application of the Concrete-Pictorial-Abstract Math Word Wall Group Competition?

\section{METHODS}

This study was a Classroom Action Research (CAR). Classroom action research usually involves the use of qualitative interpretive inquiry models and the collection of data by teachers assisted by other academics to make judgments about how to improve their practice and learning outcomes [20] (Kemmis \& Mc Taggart, 2007). CAR is implemented through the provision of treatment and improvement from one cycle to the next. The CAR cycle was shown as follows.

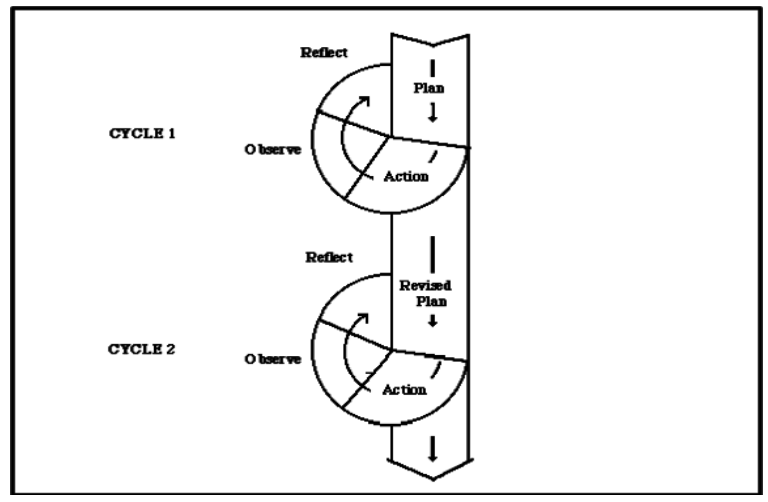

Figure 1 Kemmis-and-McTaggarts-action-researchspiral

CAR in this study wanted to know how the effect of the application of the Concrete-Pictorial-Abstract Math Word Wall Competition Group on increasing understanding of algebraic concepts when learning mathematics. The study involved 32 students (14 male students and 18 female students) in Class VIIA State Junior High School No. 12 Purworejo.

The actions given in this study are described as follows: 1) The teacher and the students discuss contextual problems on the concept of algebra, 2) The students discuss in small groups using the ConcretePictorial-Abstract approach with the help of the props that have been provided, 3) The teacher assesses the results of the work each group to create a competition between groups, 4) Class discussion to deliver the results of group work that is refuted and responded to by other groups, 5) Displaying each work result that has been assessed in the form of a math word wall, and 6)
The teacher ranks the competition standings from the assessment of the results of each group.

CAR adopts The Action Research Spiral from Kemmis \& Mc Taggart which stages each cycle consisting of Planning-Action-Observation-Reflection. This research was conducted in 3 cycles. The research instrument used a test to see an increase in the score of students 'understanding of algebraic concepts, observation sheets to see the implementation of learning and group discussions. The assessment in each cycle used 3 different types of test descriptions. Each test consists of 5 questions. Observations were carried out with the help of 3 teachers using the same observation sheet. To avoid assessment bias on observations, anticipate the following: 1) explain the description of each score of the observations to the observer so that an appropriate score can be given, 2) an evaluation is carried out at the end of the meeting to see if there is an inequality in the assessment between observers, and 3) if it occurs significant differences in a subject's observations, then it is discussed to obtain a more appropriate observation score. The questionnaire was given at the end of each cycle using 3 different types of questionnaires. Interviews were conducted by taking subjects at random.

The indicators of success in this study were there was an increase in the average algebra test score in each cycle. The increase in the average test score is measured by looking at the graph of changes in the mean test score and the T-test by comparing the average test score of a cycle with the test score of the previous cycle.

\section{RESULTS}

The results showed that the action was carried out following the planned learning. Students show good performance in group discussion activities and class discussions through the CPA approach. Students build an understanding of algebraic concepts using available teaching aids. Gradually, the students changed the concrete props into pictorials and continued with a more abstract algebraic system. This approach can produce a better understanding of algebraic concepts.

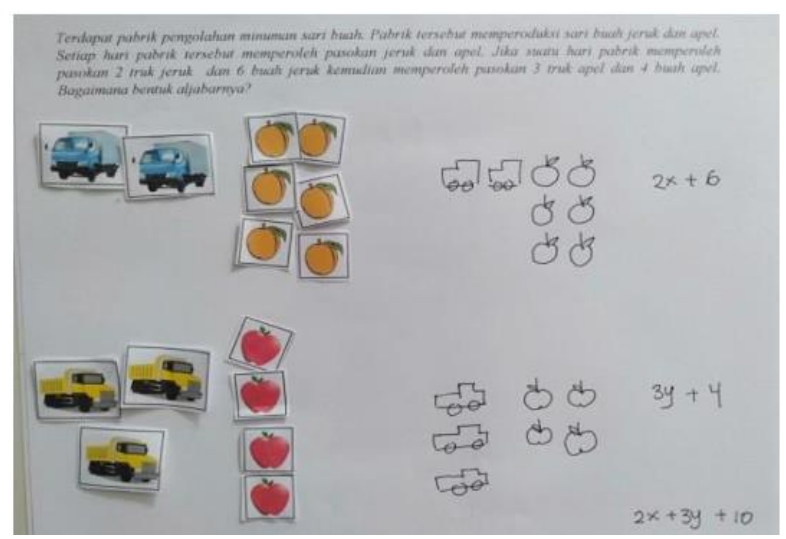

Figure 2 Teaching aids and Student Work Results with the CPA Approach 
The group discussion went well, each member of the group was able to use the CPA approach appropriately to solve the problems given and provide ideas, opinions, and corrections to the steps for completion.

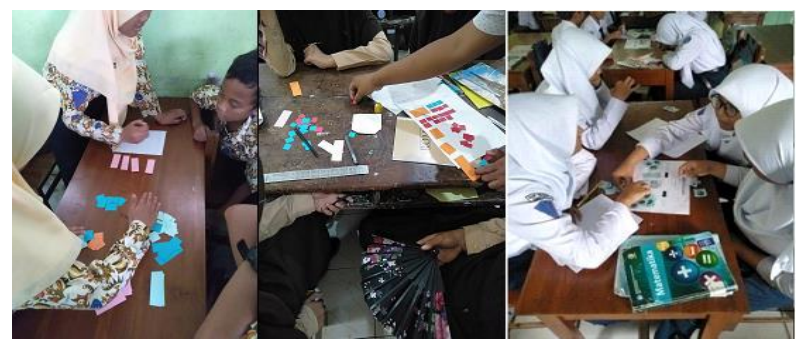

Figure 3 Group discussion with CPA approach

In general, the results of observations obtained during learning in each cycle can be seen in Table 1 below.

Table 1 shows that there has been an increase in learning activities on each indicator of learning observations. Underlined in the results of this observation are: 1) students are skilled in using teaching aids concerning the application of the CPA approach to solving problems. This has an impact on how students understand the concept of algebra appropriately, 2) Students have participated in learning with enthusiasm and joy. This can have an impact on reducing students' anxiety about learning mathematics.

Table 1. Results of the Mean Score of Learning Action Observation

\begin{tabular}{|l|l|l|l|l|}
\hline No & Observe Indicators & $\begin{array}{l}1^{\text {st }} \\
\text { Cycle }\end{array}$ & $\begin{array}{l}2^{\text {nd }} \\
\text { Cycle }\end{array}$ & $\begin{array}{l}3^{\text {rd }} \\
\text { Cycle }\end{array}$ \\
\hline 1 & $\begin{array}{l}\text { Active involvement in } \\
\text { group discussions }\end{array}$ & 56.71 & 65.21 & 78.27 \\
\hline 2 & $\begin{array}{l}\text { Active involvement in } \\
\text { class discussions } \\
\text { Seriousness in learning }\end{array}$ & 34.82 & 47.04 & 61.08 \\
\hline 3 & Seriousness in learning & 43.68 & 50.23 & 60.24 \\
\hline 4 & $\begin{array}{l}\text { Skilled in using CPA } \\
\text { props }\end{array}$ & 50.75 & 58.36 & 70.35 \\
\hline 5 & $\begin{array}{l}\text { Implement CPA for } \\
\text { troubleshooting }\end{array}$ & 47.28 & 54.37 & 65.28 \\
\hline 6 & $\begin{array}{l}\text { Placement of the } \\
\text { assessment results on the } \\
\text { math word wall }\end{array}$ & 67.86 & 78.04 & 93.66 \\
\hline 7 & $\begin{array}{l}\text { Enthusiasm for } \\
\text { involvement in learning } \\
\text { activities }\end{array}$ & 51.74 & 59.53 & 67.46 \\
\hline 8 & \begin{tabular}{l} 
Joy during learning \\
\hline
\end{tabular} & 54.78 & 62.19 & 71.64 \\
\hline
\end{tabular}

Tests are given in each cycle to see if there is an increase in understanding the concept of algebra, the results are shown in Figure 3 below.

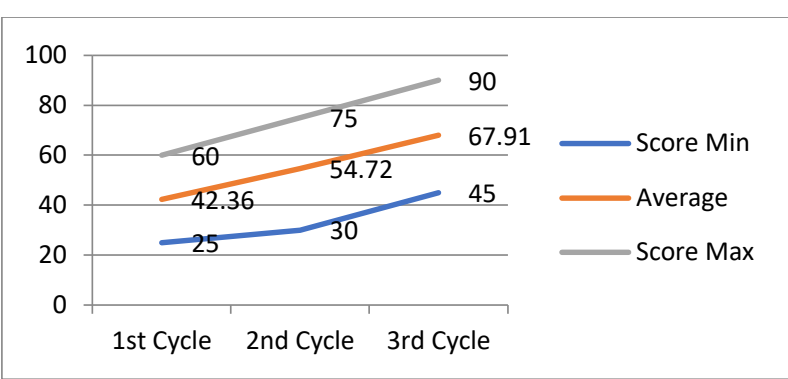

Figure 4 Graph of Concept Understanding Score Improvement

Figure 3 shows that there is an increase in the score, both in the achievement of the minimum score, the maximum score, and the average score. Then a paired sample T-test was performed to see whether the increase in the mean score was statistically significant. Statistical test using a significance level of $5 \%$.

Table 2. T-test summary on cycle 1 dan cycle 2

\begin{tabular}{|l|l|l|l|l|}
\hline $\mathrm{n}$ & $\mathrm{D}$ & $\mathrm{sd}$ & $\mathrm{T}_{\text {obs }}$ & $\mathrm{T}_{\text {tab }}$ \\
\hline 91 & 9.235 & 8,638 & 3.238 & 2.037 \\
\hline
\end{tabular}

Table 2 shows that the results of the $\mathrm{T}$ test by comparing the mean scores of the first cycle with the second cycle obtained Tobs $=3,238>2,037=$ Ttab. These results indicate that $\mathrm{H} 0$ is rejected, thus it is concluded that there is an increase in the ability to master concepts from cycle 1 to cycle 2 .

Table 3. T-test summary on cycle 2 dan cycle 3

\begin{tabular}{|l|l|l|l|l|}
\hline $\mathrm{n}$ & $\mathrm{D}$ & $\mathrm{sd}$ & $\mathrm{T}_{\text {obs }}$ & $\mathrm{T}_{\text {tab }}$ \\
\hline 91 & 10.482 & 10,164 & 4.831 & 2.037 \\
\hline
\end{tabular}

Table 2 shows that the results of the $\mathrm{T}$ test by comparing the mean scores of the first cycle with the second cycle obtained Tobs $=4.831>2,037=$ Ttab. These results indicate that $\mathrm{HO}$ is rejected, thus it is concluded that there is an increase in the ability to master concepts from cycle 2 to cycle 3 .

The two results above concluded that there has been an increase in the score of understanding the concept of algebra in each cycle. The results of statistical tests with the T-test indicate that an increase in understanding of algebraic concepts has occurred significantly.

Increased understanding of algebraic concepts in students is in line with the increasing skills of students in using CPA teaching aids and being skilled in applying the CPA approach to problem-solving. The discussion performance appraisal competition between groups also contributes to accelerating understanding of algebraic concepts. Each student in the group is encouraged to be the winner in every given task. As a result, students are motivated to improve their abilities, especially in increasing their understanding of concepts to obtain problem-solving. 
Increased understanding of concepts was also supported by interviews with 8 randomly selected students. The results of the interview stated the following: 1) students liked learning with the CPA approach, 2) students found it easy to understand the material, 3) competition between groups encouraged students to show their best abilities, 4) students felt more confident and proud of the results work, 5) competition between groups makes students more challenged, 6) students feel more comfortable during learning, 7) the use of math word wall becomes an interesting learning experience for students, 8) math word wall can be used as a means of showing themselves, 9) students feel the anxiety previously felt begins to fade, and 10) students are motivated to learn mathematics.

The findings of this study are based on data in the form of observations of the implementation of learning, concept understanding tests, and interviews. The research findings show that there is an increase in the ability to understand algebraic concepts, starting from the first cycle to the third cycle. This shows that the application of the Concrete Abstract-Abstract Mathematics Word Wall Competition Group can improve the understanding of concepts in algebra.

\section{DISCUSSION}

This study strengthens the views and results of previous studies regarding the importance of understanding concepts in algebra material for a student. This study specifically strengthens previous research that the CPA approach will improve students' conceptual understanding. These findings reinforce the previous view that the application of the CPA approach has proven effective in learning mathematical concepts [21]. The CPA approach is very effective for teaching mathematical concepts and skills [12]. The improvement of students' conceptual understanding has also proven to be effective in using it in problemsolving activities as shown by the students through the test descriptions given. This is in line with the results of the research which states that there has been a significant change in the representation achievements of students who have learned using the CPA approach [22]. The CPA approach is very appropriate to be applied to improve the mathematical connection ability of students [23]. This study complements the findings of previous studies, in which conceptual understanding, representation, and connections play a role in problemsolving activities. Thus, the CPA approach should be considered as an alternative learning approach.

It is also interesting to discuss from the findings in this study is that through the CPA approach students are quite easy to solve problems that involve several material concepts at once. This certainly implies that students' thinking skills as a result of the CPA approach can be used to learn other material concepts. This is following the opinion which states that the development of a CPA strategy in a particular concept unit also allows a smooth transition to the next learning stage [21]. Thus, this CPA approach certainly has sufficient reasons to be applied to learning other concepts besides algebra as was done in this study.

This research also shows that deliberately raised competition can accelerate the achievement of the learning objectives set. This means that the creation of a competitive atmosphere can further stimulate the thinking ability and capacity of students because the spirit of competition is always attached to each individual. However, it also needs to be investigated further, how is the impact on students with certain characteristics, for example, whether the creation of a competitive atmosphere produces different impacts on students who are optimistic and pessimistic.

Group discussions have a significant impact on reducing student criticism. Students are no longer nervous, worried, pounding, afraid, and uncomfortable because the mistakes they make can directly receive corrections from their friends. The teacher also regularly confirms what each student in the group is doing. This is in line with the opinion which emphasizes that students feel that teachers provide great benefits for themselves when teachers encourage students to share their thought processes and justify students 'answers aloud or in writing, it is the assessment of the correctness of the answers that reduce students' anxiety in mathematics [24].

Students find it easier to understand what they learn through playing CPA math worl wall because, in addition to facilitating understanding of the material, it is also able to create a happier student mood. This is following the opinion which states that students can reduce the impact of math anxiety by applying various forms of stress prevention tools [25]. CPA teaching aids can be used as an alternative means of preventing student learning stress. Competition between groups also encourages students to work harder, unite, and work together to get better results than other groups because the results of their work will be assessed, posted on the math word wall, and displayed in the competition standings.

Increasing understanding of concepts is, in principle, the key to creating a sense of comfort. When anxiety disappears, students will be able to think more positively and believe in their abilities. The selfconfidence that has been built and then faced with a competitive atmosphere further enhances a positive environment for student development. Positive selfassessment, determination, belief in the ability, and selfpotential greatly affect student learning outcomes because this attitude will foster strength and interest in students themselves [26]. 


\section{CONCLUSION}

The conclusions of this study have shown that the application of the Concrete-Pictorial-Abstract Math Word Wall Competition Group can improve conceptual understanding. This learning strategy can be used by the teacher as an alternative to learning algebraic material and other materials. Teachers need to create a positive learning environment so that and encourage students to optimize their potential to achieve learning success.

The results of this study also allow further research to be carried out by looking at the influence of the competition group on students with certain personalities. Reducing math anxiety is also important to be studied further considering that basically student anxiety changes and does not completely disappear, this is very dependent on the characteristics of the students themselves.

\section{AUTHORS' CONTRIBUTIONS}

HERU KURNIAWAN, contribute to the preparation of research designs, preparation of research instruments, class observations, and analyzing the findings.

SUPRIYONO, contribute to the preparation of research instruments, interview subjects, and analyze the findings.

TURSILOWATI, contribute to student performance assessments, subject observations, and interviews.

ISWATI JENI KUSTININGSIH, contribute to student performance assessments, subject observations, and interviews.

\section{ACKNOWLEDGMENTS}

Researchers would like to thank Purworejo Muhamamdiyah University for providing Internal Research Grants. Thank you also to the teachers and students of SMP N 12 Purworejo who were actively involved so that this research could run well.

\section{REFERENCES}

[1] S. Sengul, F. Erdogan. A Study On The Elementary Students' Perceptions Of Algebra. Procedia - Social and Behavioral Sciences, 116, 2014, pp. 3683 - 3687. doi: 10.1016/j.sbspro.2014.01.823

[2] O. A. Alghtani, N. A. Abdulhamied. The Effectiveness of Geometric Representative Approach in Developing Algebraic Thinking of Fourth Grade Students. Procedia Social and Behavioral Sciences, 8, 2010. Pp. 256-263. doi:10.1016/j.sbspro.2010.12.035

[3] G. Booker, W. Windsor. Developing Algebraic Thinking: using problem-solving to build from number and geometry in the primary school to the ideas that underpin algebra in high school and beyond. Procedia Social and Behavioral Sciences, 8, 2010. Pp. 411-419. doi:10.1016/j.sbspro.2010.12.057

[4] J. Lucariello, M. T. Tine, C. M. Ganley. A formative assessment of students' algebraic variable misconceptions. Journal of Mathematical Behavior, 33, 2014. Pp. 30-41. http://dx.doi.org/10.1016/j.jmathb.2013.09.001

[5] O. Sahin, Y. Soylu. Mistakes and misconceptions of elementary school students about the concept of vvariable. Procedia Social and Behavioral Sciences, 15, 2011. Pp. 3322-3327. doi:10.1016/j.sbspro.2011.04.293

[6] C. E. Byrd. et al.. A specific misconception of the equal sign acts as a barrier to children's learning of early algebra, Learning and Individual Differences. 2015. http://dx.doi.org/10.1016/j.lindif.2015.01.001

[7] W. Mwakapenda. Understanding student understanding in mathematics. Pythagoras 60, 2004. Pp. 28-35 in https://www.researchgate.net/publication/268008 $\underline{138}$

[8] Fatqurhohman. Pemahaman Konsep Matematika Siswa dalam Menyelesaikan Masalah Bangun Datar. Jurnal Ilmiah Pendidikan Matematika, 4(2), 2016. Pp. 127-133. Retrieved from http://ejournal.unipma.ac.id/index.php/jipm/articl e/view/847

[9] Eriana, Kartono, Sugianto. Understanding Ability of Mathematical Concepts and Students' Selfreliance towards Learning by Implementing Manipulative Props (APM) on Jigsaw Technique. Journal of Primary Education, 8 (2),

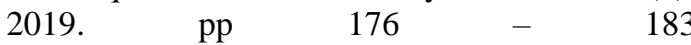
https://journal.unnes.ac.id/sju/index.php/jpe/artic le/view/25984

[10] J. N. Baker, C. J. River, J. J., Morgan, N. Reese. Teaching Algebraic Equations to Middle School Students with Intellectual Disabilities. 2015. In https://www.researchgate.net/publication/286450 $\underline{513}$

[11] N. Yahya, M. Shahrill. The Strategies used in Solving Algebra by Secondary School Repeating Students. Procedia - Social and Behavioral Sciences, 186, 2015, pp. 1192-1200. doi 10.1016/j.sbspro.2015.04.168

[12] Ministry of Education. O-level teaching and learning syllabus. Singapore: Author. 2015

[13] N. N. R. Salingay, D. A. Tan. Concrete-pictorialabstract approach on students' attitude and performance in mathematics. International 
Journal Of Scientific \& Technology Research, 7 (5), 2018, pp. $90-111$.

[14] D. A. Sousa. The Concrete-Pictorial-Abstrak Approach. [Online]. 2015. In http://www.logan schools.org/mathframework/CPA.pdf

[15] T. Hudso. Algebra Readiness through Deeper Learning

in Middle School: how teachers can empower students

to achieve with confidence. DreamBox Learning, Inc. 2015.

[16] S. McKay. Word Wall. ScaffoldedMath. 2018. In www.scaffoldedmath.com/p/pword-wall.html

[17] S. McKay. 5 ways math Word Wall have changed my teaching. ScaffoldedMath. 2017. In www.scaffoldedmath.com/2017/09/math-wordwall.html?m=1

[18] W. S. Witze. Using CRA to Teach Algebra to Students with Math Difficulties in Inclusive Settings. A Contemporary Journal, 3(2), 2015, pp. 49-60.

[19] H. E. Putri. The Influence of Concrete-PictorialAbstract

(CPA)

Approach to The Mathematical Representation Ability Achievement of the Pre-Service Teachers at Elementary School. International Journal of Education and Research, 3(6), 2015, pp. 113126.

[20] S. Kemmis, R. Mc Taggart. Participatory action research communicative action and the public sphere. Book Chapter, 2007. In 21157_Chapter_10.pdf (sagepub.com)
[21] L. Y. Hoong, H. W. Kin, C. L. Pien. ConcretePictorial-Abstract: Surveying its origins and charting its future. The Mathematics Educator 2015, 16 (1), 2015, pp. 1-19.

[22] E. P. Hafiziani. The influence of concrete pictorial abstract (cpa) approach to the mathematical representation ability achievement of the preservice teachers at elementary school, International Journal of Education and Research, 3 (6), 2015, pp. $113-125$.

[23] E. P. Hafiziani, Misnarti, D. S. Ria. Influence of concrete-pictorial-abstract (cpa) approach towards the enhancement of mathematical connection ability of elementary school students. EduHumaniora: Jurnal Pendidikan Dasar, 10 (2), 2018, pp. 61-71

[24] J. M. Furner, B. T. Berman. Review of Research: Math Anxiety:Overcoming a Major Obstacle to the Improvement of Student Math Performance. Childhood Education, 79(3), 2003, pp. 170 174. doi:10.1080/00094056.2003.10522220

[25] R. Christensen. How to reduce math anxiety. Imagine Learning Math Suite. 2017. In How to Reduce Math Anxiety [Tips that Work] | Imagine Learning

[26] O. O. Israel, O. P. Olubunmi. An Appraisal of Sciences and Mathematics Dyslexia and Dyscalculia Syndrome among Secondary Schools Students. American Journal of Educational Research, 2(4), 2014, pp. 219-224. DOI: 10.12691/education-2-4-7 